\title{
ОСОБЕННОСТИ ПРОВЕДЕНИЯ ОСЕННИХ СРОКОВ СКАШИВАНИЯ ЛУГОВЫХ ТРАВОСТОЕВ В УСЛОВИЯХ СРЕДНЕТАЕЖНОЙ ПОДЗОНЫ ЯКУТИИ*
}

N.V. Barashkova

\section{THE FEATURES OF AUTUMN TERMS OF MEADOW GRASS MOWING IN THE CONDITIONS OF THE MIDDLE TAIGA SUBZONE OF YAKUTIA}

Барашкова Наталья Владимировна - д-р с.-х. наук, гл. науч. сотр. лаб. генезиса и экологии почвенно-растительного покрова Института биологических проблем криолитозоны СО РАН, г. Якутск.E-mail: bnw-07@yandex.ru

В статье впервые представлены данные по запасным веществам в корнях сенокосных травосмесей при двуукосном использовании в условиях первой группы агроэкологических земель Приленского агроландшаффта. Объектом исследований являются сеяные травостои из районированных сортов многолетних трав в республике: пырейник изменчивый Ленский и пырейник сибирский Камалинский-7. Исследованиями установлено, что накопление водорастворимых уелеводов в корнях сеяных трав в осенний период увеличивается в 2,8-3,1 раза по сравнению с весенним. При скашивании пырейника изменчивого сорта Ленский в средний срок (1-5 сентября) при средней температуре почвы на глубине 0-20 см 11,5-12,5 ${ }^{\circ} \mathrm{C}$ содержание растворимых углеводов увеличивается с весны с 3,6 \% и осенью до 11,2\%. Скашивание одновидовых травостоев пырейников 20-25 августа при средней температуре почвы на глубине 0$20 \mathrm{~cm}$ от 13,2 до $17^{\circ} \mathrm{C}$ обеспечивает содержание кормовых единиц 0,65-0,66 и при позднем сроке (10-15 сентября) 0,65-0,67. При этом содержание переваримого протеина в 1 корм. ед. изменялось от 85 до 92 г. Травосмесь, состоящая из пырейников изменчивого и сибирского, сохраняет хорошее качество сенокосного корма при среднем сроке скашивания 1-5 сентября при средней температуре почвы на глубине 0$20 \mathrm{~cm}$ om 11,5 до $12,5^{\circ} \mathrm{C}$ c содержанием кормовых единиц до 0,64 и переваримого протеина
Barashkova Natalya Vladimirovna - Dr. Agr. Sci., Chief Staff Scientist, Lab. of Genesis and Ecology of Soil and Plants Cover, Institute of Biological Problems of Permafrost SB RAS, Yakutsk.

E-mail: bnw-07@yandex.ru

в 1 корм. ед. до 93 г. Полученные данные свидетельствуют о возможности скашивания злаковой травосмеси до 1-5 сентября без ущерба качества корма с учетом накопления запасных веществ в осенний период.

Ключевые слова: сеяные травы, пырейни$к и$ запасные вещества, углеводы, крахмал, гемииеллюлоза, биохимический анализ, качество корма, агроландшафот.

The study was the first to present the data on reserve substances in the roots of haymaking grass mixtures for double-crop use under conditions of the first group agroecological lands of the NearLena agricultural landscape. The object of the study was seeded grass stands of recognized in the Republic varieties of perennial grasses: Elymus mutabilis Lensky and Elymus sibiricus Kamalinsky7. It was proved by the studies that the content of water-soluble carbohydrates in the roots of seeded grasses in the autumn period increased by 2.8-3.1 times in average as compared to spring. The stands of Elymus mutabilis of Lensky variety mowed within average dates (September, 1-5) at average soil temperature $11.5-12.5^{\circ} \mathrm{C}$ at the depth of 0-20 cm, showed the increase of soluble carbohydrates content from $3.6 \%$ in spring to $11.2 \%$ in autumn. Mowing Elymus mutabilis stands on August, 20-25 at average soil temperature from 13.2 to $17{ }^{\circ} \mathrm{C}$ provides feed content of $0.65-0.66$ and $0.65-0,67$ at a late date (September, 10-15). Be-

*Научные исследования выполнены по заданию базового проекта VI.52.1.8. «Фундаментальные и прикладные аспекты изучения разнообразия растительного мира Северной и Центральной Якутии» рег. № АAAA-A71-117020110056-0 в рамках госзадания ИБПК 
sides, the content of digestible protein in 1 feed unit varied from 85 to $92 \mathrm{~g}$. The grass mixture consisting of both Elymus mutabilis and Elymus sibiricus maintained good productivity within the average mowing dates of September, 1-5 at average soil temperature 11.5 to $12.5^{\circ} \mathrm{C}$ with forage content units to 0.64 and digestible protein in 1 feed units up to $93 \mathrm{~g}$ of raw protein. The obtained data testify of possible mowing of the grass mixture before September, 1-5 without any harm to feed quality, taking into account the accumulation of reserve substances in the autumn period.

Keywords: seeded herbs, elymus, reserve substances, carbohydrates, starch, hemicellulose, biochemical analysis, feed quality, agrolandscape.

Введение. В 2016 г. в Норвегии состоялось Генеральное собрание Европейской федерации луговодов, где рассматривались климатические изменения и их влияние на луговые системы Средиземноморья и Северной Европы. Реакция луговых трав на изменения климата проявляется разнообразно в зависимости от условий произрастания и продления вегетации. Весьма актуальным в условиях криолитозоны является реакция сенокосных травостоев при повышении температуры весной на поверхностном слое почвы, увеличении количества осадков в засушливый период лета и удлинении продолжительности вегетации. Продолжительность вегетационного периода отражается благоприятно на ростовых процессах, особенно весной, когда наблюдается высокая влагообеспеченность и солнечная радиация.

В последнее время появились новые данные, уточняющие продолжительность периода между предпоследними и последними сроками скашивания луговых трав в связи с изменением климата, особенно с учетом теплообеспечености и продолжительности осенних периодов. При сроке осеннего (последнего) срока скашивания луговые травы успевают накопить в зимующих органах достаточно запасных веществ и при этом после последнего укоса не расходуют их на новое отрастание. Интервал между предпоследними и последними укосами различается в зависимости от вида трав и длительности потребления питательных веществ и органов запаса после скашивания, а также от интенсивности и распределения запасных веществ.
Важным показателем уровня устойчивости растений при перезимовке является интенсивность накопления и расходования углеводов. В осенний период в отаве многолетних трав повышается содержание углеводов вследствие перемещения запасных веществ в корни и корневища, а также установлена различная реакция многолетних трав на последнее отчуждение. С.П. Смелов [1] установил, что растения хорошо зимуют, если они уходят в зиму с хорошей розеткой, состоящей из укороченных побегов с зачаточным стеблями, и имеют больше питательных веществ в корнях. Последнее во многом в значительной мере зависит от срока последнего скашивания.

В условиях Якутии подробно изучили витаминный, биохимический и минеральный состав дикорастущих кормовых трав и сена А.Д. Егоров [2], химический состав пастбищных и тебеневочных растений М.Ф. Габышев, А.В. Казанский [3]. Просрессор Л.Г. Еловская [4] исследовала зависимость химического состава луговых трав от условий почвенного питания. Углеводный состав и содержание лигнина в кормовых травах СевероВосточной и Центральной Якутии изучал В.Я. Потапов [5]. Он установил, что в условиях Якутии запасными углеводами наиболее богаты естественные злаковые и осоковые травы - до $30 \%$, в некоторых случаях оно достигает 33-35\%. Так, в подземных органах (корни и корневища) пырея ползучего наряду с большим количеством растворимых углеводов накапливаются также сахар и крахмал до 15,5 \%.

В условиях Центральной Якутии на естественных травостоях предлагают проводить осеннее отчуждение за 20-30 дней до конца вегетации $[6,7]$. В настоящее время отсутствуют экспериментальные данные о динамике и накоплении запасных веществ в корнях сеяных трав при разных сроках осеннего скашивания и их влиянии на питательность корма в условиях Приленского агроландшафта.

Цель исследований. Изучение влияния накопления запасных веществ в корнях пырейника изменчивого и сибирского, а также злаковой травосмеси на качество сенокосного корма в условиях Приленского агроландшафрта среднетаежной зоны Якутии в зависимости от сроков осеннего скашивания. 
Методика и условия исследований. Исследования проводилась на территории Приленского агроландшафрта в долине Средней Лены. По данным Л.С. Ивановой $[8,9]$, Приленский агроландшафрт расположен в Лено-Алданском междуречье и занимает 3,0 тыс. км² земель, или $6,0 \%$ территории. Представляет собой эрозионно-аккумулятивную равнину с абсолютной высотой 140-170 м, отделяется уступом 1020 м от Чурапчинского агроландшафта. Полевые исследования по влиянию различных сроков осеннего скашивания сеяных трав на накопление запасных веществ в корнях и качество корма проведены в условиях первой агроэкологической группы земель Приленского агроландшафта, которая расположена на умеренно и слабодренированных землях поймы р. Лены и занимает 0,24 тыс. кв. м.

Климат Приленского агроландшафтта формируется в условиях повсеместного развития многолетней мерзлоты и своеобразного гидрологического режима р. Лены и характеризуется большей теплообеспеченностью и засушливостью. Вегетационный период длиннее на 15-20 дней, сумма температур воздуха $10{ }^{\circ} \mathrm{C}$ выше на 100-200 ${ }^{\circ} \mathrm{C}$. Весной дата перехода среднесуточной температуры воздуха через $10^{\circ} \mathrm{C}$ происходит в конце мая. В Приленском агроландшафте за летний период благодаря достаточной теплообеспеченности мерзлые песчаные грунты протаивают до глубины 2,0-2,5 м.

При выращивании многолетних трав на землях первой агроэкологической группы Приленского агроландшафтта следует учитывать их устойчивость к длительному затоплению. Ранневесеннее затопление до 30-43 дней выдерживают бекмания, лисохвост луговой, кострец безостый, пырей ползучий, мышиный горошек. Из бобовых люцерна среднеустойчива к затоплению. Низовые злаки овсяница луговая, мятлик луговой - слабоустойчивы. При летней повышенной температуре воздуха многолетние травы выдерживают затопление не более 20-26 часов $[9,10]$.

Создание сеяного травостоя проведено залужением с использованием районированных сортов: пырейника сибирского (сорт Камалинский-7), пырейника изменчивого (сорт Ленский). Срок посева сеяных трав - летний, способ посева - беспокровный, рядовой с междурядьями 15 см. Нормы высева пырейника сибирского сорта Камалинский-7 - 20 кг/га, пырейника изменчивого сорта Ленский - 16 кг/га при 100\%-й хозяйственной годности. Опыты заложены методом рендоминизации в четырехкратной повторности: учетная площадь $25 \mathrm{~m}^{2}$. Согласно схеме опыта, при двухукосном использовании сеяного травостоя первый укос проводили в фазу массового колошения, второй укос через 50 55 дней. Агротехника обработки почвы проведена согласно зональной системе [10].

Наблюдения и учеты на опытах проводились по общепринятым методикам ВНИИК $[11,12]$. Дисперсионный анализ данных проведен по Б.А. Доспехову [13]. Температуру почвы в слое 0-20 см замеряли комплектом термометров Саввинова. Запасные вещества в корнях сеяных трав (водорастворимые углеводы, крахмал, гемицеллюлоза) определяли в биохимической лаборатории Якутского НИИСХ СО РАН.

Результаты и их обсуждение. Запасные углеводы состоят из водорастворимых углеводов, крахмала и гемицеллюлозы. Гемицеллюлоза как сахар и крахмал выполняет роль запасных питательных веществ и может вторично вовлекаться в обменные процессы и служить энергетическим материалом. В условиях Приленского агроландшафта среднетаежной подзоны Якутии наиболее высокое накопление запасных веществ отмечается в подземных органах в конце вегетации растений. Исследования В.Я. Потапова [5] доказали зональную особенность луговых трав Якутии, которые более богаты сахарами, чем травы, произрастающие в средней полосе и на Дальнем Востоке. При этом отмечено отсутствие больших скачков в динамике содержания растворимых углеводов и гемицеллюлозы. По-видимому, высокое содержание запасных углеводов в луговых травах криолитозоны объясняется суточной продолжительностью и интенсивностью фотосинтеза, а также преждевременным ослаблением ростовых процессов в связи с понижением температур воздуха в ночное время, которые способствует образованию углеводов.

Полученные результаты исследований доказали, что накопление водорастворимых углеводов в корнях сеяных трав в осенний период увеличивается в 2,8-3,1 раза по сравнению с весенними (табл. 1). При скашивании пырейника изменчивого сорта Ленский в средний срок (1-5 сентября) при средней температуре почвы 11,5$12,5^{\circ} \mathrm{C}$ на глубине 0-20 см накопление растворимых углеводов увеличивается с весны от 3,6 до 11,2 \% осенью. 
Динамика накопления и содержание запасных углеводов в корнях сеяных трав в зависимости от различных сроков осеннего скашивания, \%

\begin{tabular}{|c|c|c|c|c|c|c|c|c|}
\hline \multirow[t]{2}{*}{ Вид трав } & \multicolumn{2}{|c|}{$\begin{array}{c}\text { Водорастворимые } \\
\text { углеводы }\end{array}$} & \multicolumn{2}{|c|}{ Крахмал } & $\begin{array}{c}\text { Гемицел- } \\
\text { люлоза }\end{array}$ & $\begin{array}{l}\text { Раствори- } \\
\text { мые } \\
\text { углеводы }\end{array}$ & $\begin{array}{l}\text { Крах- } \\
\text { мал }\end{array}$ & \multirow[t]{2}{*}{$\begin{array}{l}\text { Запасные } \\
\text { углеводы }\end{array}$} \\
\hline & Весна & Осень & Весна & Осень & \multicolumn{3}{|c|}{ Корни } & \\
\hline \multicolumn{9}{|c|}{ Ранний срок скашивания (20-25 августа) - контроль } \\
\hline $\begin{array}{l}\text { Пырейник } \\
\text { изменчивый, } \\
\text { сорт Ленский }\end{array}$ & 3,9 & 11,0 & 1,7 & 3,2 & 10,58 & 11,0 & 3,2 & 24,80 \\
\hline $\begin{array}{l}\text { Пырейник } \\
\text { сибирский, сорт } \\
\text { Камалинский-7 }\end{array}$ & 6,8 & 9,6 & 2,1 & 2,4 & 12,33 & 9,6 & 2,4 & 24,33 \\
\hline $\begin{array}{l}\text { 3лаковая } \\
\text { травосмесь }\end{array}$ & 4,8 & 11,3 & 2,5 & 2,5 & 10,91 & 11,3 & 2,5 & 24,71 \\
\hline \multicolumn{9}{|c|}{ Средний срок скашивания (1-5 сентября) } \\
\hline $\begin{array}{l}\text { Пырейник } \\
\text { изменчивый, } \\
\text { сорт Ленский }\end{array}$ & 3,6 & 11,2 & 2,1 & 3,0 & 8,60 & 11,2 & 3,0 & 22,80 \\
\hline $\begin{array}{l}\text { Пырейник } \\
\text { сибирский, сорт } \\
\text { Камалинский-7 }\end{array}$ & 4,3 & 11,1 & 1,5 & 3,2 & 16,00 & 11,1 & 3,2 & 30,30 \\
\hline $\begin{array}{l}\text { Злаковая } \\
\text { травосмесь }\end{array}$ & 5,2 & 9,0 & 2,0 & 2,4 & 12,41 & 9,0 & 2,4 & 23,81 \\
\hline \multicolumn{9}{|c|}{ Поздний срок скашивания (10-15 сентября) } \\
\hline $\begin{array}{l}\text { Пырейник } \\
\text { изменчивый, } \\
\text { сорт Ленский }\end{array}$ & 4,4 & 8,2 & 1,2 & 3,0 & 16,66 & 8,2 & 3,0 & 27,86 \\
\hline $\begin{array}{l}\text { Пырейник } \\
\text { сибирский, сорт } \\
\text { Камалинский-7 }\end{array}$ & 3,9 & 11,0 & 1,4 & 3,0 & 18,50 & 11,0 & 3,0 & 32,50 \\
\hline $\begin{array}{l}\text { Злаковая } \\
\text { травосмесь }\end{array}$ & 5,7 & 9,5 & 1,6 & 2,3 & 15,50 & 9,5 & 2,3 & 27,30 \\
\hline
\end{tabular}

При этом накопление крахмала в корнях не изменяется и находится на уровне $3,0 \%$. Аналогичная закономерность по накоплению углеводов в корнях отмечается и у пырейника сибирского сорта Камалинский-7. Иная тенденция наблюдается у злаковой травосмеси, состоящей из пырейника изменчивого сорта Ленский и пырейника сибирского сорта Камалинский-7. Наибольшее накопление растворимых углеводов $(11,3 \%)$ у злаковой травосмеси отмечается при раннем сроке скашивания (20-25 августа) при средней температуре почвы $13,2-17{ }^{\circ} \mathrm{C}$ на глубине 0-20 см.

Одновидовые травостои пырейника изменчивого при поздних сроках осеннего скашивания в корнях накапливают до 27,86 \% запасных уг- леводов, что способствует хорошей перезимовке трав без ущерба урожайности и ухудшения качества сенокосного корма (табл. 2). Важную роль во всех процессах обмена веществ играют белки, которые в одновидовых травостоях пырейника изменчивого при раннем сроке скашивания составили $18,2 \%$, а при позднем сроке последнего скашивания снизились до 17,0\%. Закономерность снижения содержания сырого протеина наиболее четко проявляется при средних и поздних сроках последнего скашивания в злаковой травосмеси от 18,6 до 16 \% и от 16,9 до $15,1 \%$ CВ.

Значение углеводов в жизни растений огромно, так как сахара и крахмал играют основную роль в процессах фотосинтеза и дыхания. 
Содержание сырой клетчатки в целом повышенное и в одновидовых травостоях изменяется от 33,4 до 31,1 \% СВ. Минимальное содержание сырой клетчатки в первом укосе $(31,1 \%)$ отмечается при позднем сроке скашивания у пырейника изменчивого сорта Ленский, а максимальное $(33,4 \%)$ у пырейника сибирского на раннем осеннем скашивании.
Содержание сырой золы не превышало нормы и по мере удлинения сроков скашивания снижается от 8,3 до 7,5 \% СВ. Содержание БЭВ варьировало в пределах 37,22-43,55 \% в зависимости от вида трав и сроков осеннего скашивания. При этом характерно сравнительно низкое содержание БЭВ во втором укосе на контроле - 37,88-36,97\%.

Таблица 2

Качество сена, полученного в одновидовых и смешанных посевах, в зависимости от различных сроков осеннего скашивания в условиях Приленского агроландшафта

\begin{tabular}{|c|c|c|c|c|c|c|c|c|}
\hline \multirow[b]{2}{*}{ Вид трав } & \multicolumn{5}{|c|}{ Содержание, \% в СВ } & \multirow[b]{2}{*}{$\begin{array}{c}\text { Содер- } \\
\text { жание, } \\
\text { корм. ед. }\end{array}$} & \multirow{2}{*}{$\begin{array}{c}\text { Перева- } \\
\text { римый } \\
\text { протеин, } \\
\text { г/корм. } \\
\text { ед. }\end{array}$} & \multirow{2}{*}{$\begin{array}{c}\text { Класс- } \\
\text { ность } \\
\text { сена } \\
{[14]}\end{array}$} \\
\hline & $\begin{array}{l}\text { Сырой } \\
\text { протеин }\end{array}$ & $\begin{array}{c}\text { Сырая } \\
\text { клетчат- } \\
\text { ка }\end{array}$ & $\begin{array}{l}\text { Сырой } \\
\text { жир }\end{array}$ & $\begin{array}{l}\text { Сырая } \\
\text { зола }\end{array}$ & БЭВ & & & \\
\hline \multicolumn{9}{|c|}{ Ранний срок скашивания (20-25 августа) - контроль } \\
\hline $\begin{array}{l}\text { Пырейник изменчи- } \\
\text { вый, сорт Ленский }\end{array}$ & 18,2 & 32,8 & 2,6 & 8,3 & 38,1 & 0,65 & 85,0 & 2 \\
\hline $\begin{array}{l}\text { Пырейник сибирский, } \\
\text { сорт } \\
\text { Камалинский-7 }\end{array}$ & 17,2 & 33,4 & 2,5 & 7,8 & 39,1 & 0,66 & 92,4 & 1 \\
\hline Злаковая травосмесь & 17,0 & 32,3 & 2,7 & 8,0 & 40,0 & 0,61 & 84,1 & 2 \\
\hline \multicolumn{9}{|c|}{ Средний срок скашивания (1-5 сентября) } \\
\hline $\begin{array}{l}\text { Пырейник изменчи- } \\
\text { вый, сорт Ленский }\end{array}$ & 18,6 & 31,8 & 2,8 & 8,2 & 38,6 & 0,64 & 77,0 & 2 \\
\hline $\begin{array}{l}\text { Пырейник сибирский, } \\
\text { сорт } \\
\text { Камалинский-7 }\end{array}$ & 16,4 & 31,8 & 2,7 & 7,6 & 41,5 & 0,61 & 88,0 & 2 \\
\hline Злаковая травосмесь & 16,0 & 31,8 & 2,9 & 7,8 & 41,5 & 0,64 & 93,0 & 2 \\
\hline \multicolumn{9}{|c|}{ Поздний срок скашивания (10-15 сентября) } \\
\hline $\begin{array}{l}\text { Пырейник изменчи- } \\
\text { вый, сорт Ленский }\end{array}$ & 16,9 & 31,1 & 2,8 & 7,8 & 41,4 & 0,65 & 92,5 & 2 \\
\hline $\begin{array}{l}\text { Пырейник сибирский, } \\
\text { сорт } \\
\text { Камалинский-7 }\end{array}$ & 16,1 & 32,7 & 2,6 & 7,5 & 41,1 & 0,67 & 81,4 & 2 \\
\hline Злаковая травосмесь & 15,1 & 31,8 & 2,8 & 7,5 & 42,8 & 0,53 & 57,4 & 2 \\
\hline
\end{tabular}

По производству кормовых единиц большой разницы не отмечается как в чистых посевах, так и в травосмеси - от 0,61 до 0,67, что позволяет отнести сенокосный корм ко 2-му классу согласно ОСТ-10243-2001 [14]. По следующим показателям (сырой протеин, корм. ед., переваримовый протеин, корм. ед.) сенокосный корм из пырейника сибирского сорта Камалинский-7 при раннем сроке скашивания можно отнести к 1-му классу.

Заключение. В условиях Приленского агроландшафтта удлинение осенних сроков скаши- вания до 1-5 сентября не снижает накопления запасных веществ в корнях, способствуя хорошей перезимовке и сохранению качества сенокосного корма. Сенокосный корм при осенних сроках скашивания по качеству не уступал кормам, полученным в традиционные сроки сенокошения. При этом питательность сеяного травостоя чуть ниже зоотехнической нормы - 93 г на 1 кормовую единиц, а по сырому протеину (от 15,1 до 18,6 \% СВ) можно его отнести к 1-му классу. 


\section{Литература}

1. Смелов С.П. Теоретические основы луговодства. М., 1966. 366 с.

2. Егоров А.Д. Химический состав и питательность сена центральных районов Якутии. М., 1960. 334 с.

3. Габышев М.Ф., Казанский А.В. Кормовые травы Якутии. Якутск, 1957. 153 с.

4. Еловская Л.Г. Влияние почвенных условий на химизм и питательную ценность некоторых кормовых растений Центральной Якутии // Тр. Ин-та биологии ЯФ СО АН СССР. Якутск, 1958. Вып.5.

5. Потапов В.Я. Углеводы и лигнин в кормовых травах Якутии. М., 1967. 124 с.

6. Алексеева Л.В. Приемы удобрений и интенсивного использования пойменных лугов Центральной Якутии: автореф. дис. ... канд. С.-х. наук. М., 1973. 15 с.

7. Аржаков В.И. Режим использования пойменных лугов Центральной Якутии при различном увлажнении и уровне азотного питания: автореф. дис. ... канд. с.-Х. наук. М., 1984. 15 C.

8. Иванова Л.С. Адаптивно-ландшафртные системы земледелия Лено-Амгинского междуречья. Новосибирск, 2004. 132 с.

9. Иванова Л.С. Агроландшафтное районирование и агроэкологическая группировка земель среднетаежной подзоны Якутии для проектирования адаптивно-ландшафтных систем земледелия. Новосибирск, 2018. 113 с.

10. Система ведения сельского хозяйства в Республике Саха (Якутия) на период 20162020 годы: метод. пособие. Якутск, 2017. $415 \mathrm{c}$.

11. Методические указания по проведению полевых опытов с кормовыми культурами / Ю.К. Новоселов [и др.]. М., 1983.197 с.

12. Методическое пособие по агроэнергетической и экономической оценке технологий и систем кормопроизводства / Б.П. Михайличенко [и др.]. М., 1995. 208 с.

13. Доспехов Б.А. Методика полевого опыта. М.: Колос, $1985.347 \mathrm{c}$.

14. Стандарт отрасли. ОСТ 10 273-2001. Корма зеленые (технические условия). М., 2001. $10 \mathrm{c}$.

\section{Literatura}

1. Smelov S.P. Teoreticheskie osnovy lugovodstva. M., 1966. $366 \mathrm{~s}$.

2. Egorov A.D. Himicheskij sostav i pitatel'nost' sena central'nyh rajonov Jakutii. M., 1960. $334 \mathrm{~s}$.

3. Gabyshev M.F., Kazanskij A.V. Kormovye travy Jakutii. Jakutsk, 1957. $153 \mathrm{~s}$.

4. Elovskaja L.G. Vlijanie pochvennyh uslovij na himizm i pitatel'nuju cennost' nekotoryh kormovyh rastenij Central'noj Jakutii // Tr. In-ta biologii JaF SO AN SSSR. Yakutsk, 1958. Vyp.5.

5. Potapov V.Ja. Uglevody i lignin $\mathrm{v}$ kormovyh travah Jakutii. M., 1967. $124 \mathrm{~s}$.

6. Alekseeva L.V. Priemy udobrenij i intensivnogo ispol'zovanija pojmennyh lugov Central'noj Jakutii: avtoref. dis. ... kand. s.-h. nauk. M., 1973. $15 \mathrm{~s}$.

7. Arzhakov V.I. Rezhim ispol'zovanija pojmennyh lugov Central'noj Jakutii pri razlichnom uvlazhnenii i urovne azotnogo pitanija: avtoref. dis. ... kand. s.-h. nauk. M., $1984.15 \mathrm{~s}$.

8. Ivanova L.S. Adaptivno-landshaftnye sistemy zemledelija Leno-Amginskogo mezhdurech'ja. Novosibirsk, 2004.132 s.

9. Ivanova L.S. Agrolandshaftnoe rajonirovanie i agrojekologicheskaja gruppirovka zemel' srednetaezhnoj podzony Jakutii dlja proektirovanija adaptivno-landshaftnyh sistem zemledelija. Novosibirsk, 2018. $113 \mathrm{~s}$.

10. Sistema vedenija sel'skogo hozjajstva v Respublike Saha (Jakutija) na period 2016-2020 gody: metod. posobie. Jakutsk, 2017. 415 s.

11. Metodicheskie ukazanija po provedeniju polevyh opytov s kormovymi kul'turami / Ju.K. Novoselov [i dr.]. M., $1983.197 \mathrm{~s}$.

12. Metodicheskoe posobie po agrojenergeticheskoj i jekonomicheskoj ocenke tehnologij i sistem kormoproizvodstva / B.P. Mihajlichenko [i dr.]. M., 1995. $208 \mathrm{~s}$.

13. Dospehov B.A. Metodika polevogo opyta. M.: Kolos, 1985. $347 \mathrm{~s}$.

14. Standart otrasli. OST 10 273-2001. Korma zelenye (tehnicheskie uslovija). M., 2001. $10 \mathrm{~s}$. 